practical help to pathologists called upon to unravel the intricacies of these often puzzling anomalies.

\section{T. CRAWFORD}

OCCLUSION OF THE SUPERIOR MESENTERIC ARTERY BY Benjamin B. Jackson. (Pp. xiv $+141 ; 41$ figures. \$7.50.) Springfield, Illinois: Charles C. Thomas. 1963. The author, a surgeon, has based this monograph on his own clinical and experimental work and on some 1,500 cases of acute and chronic mesenteric artery insufficiency which have, so far, been reported in the literature. The various aspects of mesenteric artery occlusion are considered and the resulting account is well balanced. While the book will probably be of most interest to surgeons, pathologists and others will find much of value in it.

P. D. STEWART

THE PATHOGENESIS OF LeProsy Ciba Foundation Study Group No. 15. Edited by G. E. W. Wolstenholme and Maeve O'Connor. (Pp. ix $+101 ; 19$ figures. 15s.) London: J. \& A. Churchill Ltd. 1963.

This is a record of papers read at a special study group in 1963 and of the discussions which followed. Anyone interested in leprosy or Mycobacteria generally will find, in this small volume, much valuable information concerning recent experimental and research work into the pathogenesis of leprosy.

P. D. STEWART

PROGRESS IN MEDICAL LABORATORY TECHNIQUE 2 Edited by F. J. Baker. (Pp. vii +191 ; illustrated. $35 s$.) London: Butterworth \& Co. Ltd. 1963.

This is the second in a series of articles on new laboratory techniques written by those well versed in them. In comparison with the first it is disappointing. The methods are well described but highly specialized and on the whole are suitable for those working in reference or research laboratories. Those finding this book useful in one subject will have little practical use for the methods described in the others. There are 10 articles all by experienced technicians: two are histological, one chemical, two about cardiovascular bypass, three on haematology, one on bacteriology, and one on virology.

Some of the articles need more drastic editing. For example, advice on Mantoux tests and chest radiographs for laboratory staff is out of place as it is not laboratory technique and has been standard practice for many years. In the same chapter hypochlorite is recommended for pipette disinfection but no strength is given. A method for pyrazinamide sensitivity would have been valuable and also advice on weighing tubercle bacilli safely. Both are mentioned but no details are given.
The book is well set out, clearly printed, and for the्ष most part easy to read. The price is reasonable. JOAN STOKES

AUTOMATION IN CLINICAL CHEMISTRY By Walton Wס Marsh. (Pp. xiv $+132 ; 38$ figs. \$6.00.) Springfield응

Illinois: Charles C. Thomas. 1963.

This little book is a valuable quick reference to automatio techniques which can be applied in clinical chemicaf laboratories. Its greatest value will be for those who ares contemplating the introduction of machines such as the Technicon AutoAnalyzer into their departments. Theearly chapters on the principles of the various types of apparatus are the most helpful and the author discusses? many practical points not mentioned elsewhere. Thif aspect could well be expanded in a later edition. The description of individual methods inevitably leads to a discussion of dated techniques though there is much of interest in the less familiar methods using such apparatuso as the Benchtop Robot Biochemist.

J. RIDEOUT and M. G. RINSLER

\section{CORRECTION}

The author of 'Quantitative estimation of formimino? glutamic acid in urine' (J. clin. Path., 17, 466) wishes to make the following amendments. The eighth sentence of the Procedure should read 'The resultant coloured" solutions are transferred to small cuvettes of $1 \mathrm{~cm}$. liggt $\overrightarrow{-}$ path and the optical densities measured, without delay, at $540 \mathrm{~m} \mu$ using the solutions from the corresponding non-ammoniated spots as a blank'. The eleventh senteriseo should read 'The tubes are stoppered, the stained spots eluted for about 5-10 minutes with occasional shakingo and centrifuged if the eluate shows any turbidity. The eluate is measured at $525 \mathrm{~m} \mu$ '.

CLINICAL CHEMICAL PATHOLOGY, 3rd ed. By C. H. Gray. (Pp. viii $+196 ; 32$ figures. 16s.) London: Edward Arnold. 1963.

This is the third edition of a valuable little book. It contains the chemical pathology that an undergraduate medical student must learn set out in very readable and: comprehensible form. The whole book can be read in an 3 evening: it should be in the possession of every medical student. ARTHUR JORDAN

\section{BOOK RECEIVED}

(Review in a later issue is not precluded by notice here of books recentl received.)

ENDocrinology By A. Stuart Mason. (Pp. 136. 36s.) London: Staples Press. 1963. 